\title{
PPIF Gene
}

National Cancer Institute

\section{Source}

National Cancer Institute. PPIF Gene. NCI Thesaurus. Code C118234.

This gene is involved in both protein folding and mitochondrial permeability transition pore activity. 